\title{
Diabetogenic Zinc Binding B-Cytotoxic Chemicals: Mechanisms of Action and Methods for Prevention of Diabetes
}

\section{Gabit G Meyramov*and Aizhan G Abdraimova Meyramova}

Diabetes Research Group, Karaganda State Medical University, Karaganda, Kazakhstan

*Corresponding author: Gabit G Meyramov, Diabetes Research Group, Karaganda State Medical University, Karaganda, Kazakhstan, Tel: 77212563253; E-mail: meyramow@mail.ru

Received date: June 29, 2016; Accepted date: June 29, 2016; Published date: July 07, 2016

Citation: Meyramov GG, Meyramova AGA (2016) Diabetogenic Zinc Binding B-Cytotoxic Chemicals: Mechanisms of Action and Methods for Prevention of Diabetes. J Obes Eat Disord 2: 2. doi: 10.21767/2471-8203.100019

Copyright: (c) 2016, Gabit G Meyramov. This is an open-access article distributed under the terms of the Creative Commons Attribution License, which permits unrestricted use, distribution, and reproduction in any medium, provided the original author and source are credited.

\section{Abstract}

Mechanisms of diabetogenic action of diabetogenic zincbinding chemicals (DZBC) as Dithizon and derivatives of 8-oxyquinolin and methods of prevention of diabetes caused by their were investigated. It was established that: a) injection of diabetogenic doses of DZBC as 30-50 $\mathrm{mg} / \mathrm{kg}$ result forming in bytoplasm of B-cells of chelat complexes $\mathrm{Zn}$-DZBC within a few minutes; b) by electron microscopy it was showed that presence of complex in Bcells within 15-20 min result destruction and death of majority B-cells and developing of 1 type diabetes in animals; c) destruction of B-cells started by destroying of B-granules concentrated deposited form of insulin as $\mathrm{Zn}$ insulin; d) prevention of formation of comlex in B-cells by 2 ways (complete elimination of $\mathrm{Zn}$-ions from B-cells by Glibenclamide or binding of $\mathrm{Zn}$-ions by not diabetogenic chelators as $\mathrm{Na}$ salt of Diethyldithiocarbamic acid, by Cystein and recovered form of Glutathion completely protect B-cells of formation of complex and of developing of diabetes in $85-95 \%$ of animals for period of binding of $\mathrm{Zn}$-ions (12-24 h); e) Xanthurenic Acid formed in animals and human as result of disturbances of tryptophan metabolism possess same mechanism of action as other DZBC but diabetes developed more slowly because XA is synthesised in organism more slowly that is why not possible to destroy majority of B-cells as in result of injection of diabetogenic doses of other DZBC; $f$ ) they are only one real way for prevention action of XA- partial or mo complete inhibition of endogene synthesis of $X A$ by administration of Pyridoxine ( $P$ ) within long time due to ability of $P$ to restore amount of Pyridoxal-5-Phosphate which protect endogene synthesis of $X A$; two other ways (elimination of $\mathrm{Zn}$-ions and not diabetogenic binding of its) not possible to use for protect developing of diabetes or to reduce its symptoms.

\section{Introduction}

More than 80 years ago A Scott and D Fischer were separated insulin from the native pancreas as insulin- $\mathrm{Zn}^{+2}$ complex and supposed that the presence of $\mathrm{Zn}^{+2}$-ions determined physiological activity of insulin. Interest to this problem was increased after reporting by these authors that in pancreas of diabetic patients total amount of $\mathrm{Zn}$ is not more than $50 \%$ in compared with non-diabetic men.

The amount of $\mathrm{Zn}^{+2}$ is evidently decreased in experimental diabetes induced by any causes. $\mathrm{Zn}^{+2}$ is able to accumulate in pancreas tissue. By aid of electron histochemical microscopy it was confirmed that in B-cells $\mathrm{Zn}^{+2}$-ions are located in $\mathrm{B}$ granules contains deposited form of insulin.

1. 1964-1967. Analysis of problem; mastering of research methods.

2. 1967-1977. Investigation of mechanisms of Diabetogenic Zinc binding [1] B-cytotoxic Chemicals, DZBC [2-5] (derivatives of 8-oxyquinolin and Dithizon) and methods for prevention of diabetes caused by their.

\section{Methods}

Animals: rabbits and rats. Histological and Histochemical methods for staining of insulin and of $\mathrm{Zn}^{+2}$-ions were used: Methods: aldehyde-fucshine, fluorescent pseudoisocyanine method, immunohistochemical method, Victoria-4R, Dithizon histochemical method and high specific fluorescent method for staining of $\mathrm{Zn}^{+2}$-ions; transmission electron microscopy; method of isolation of pancreatic islets by using of Collagenase was used for to investigate direct action of DZBC on B-cells on model of tissue culture.

\section{Results}

a)DZBC formed in B-cells toxic chelat complexes with $\mathrm{Zn}^{+2}$ ions that result destruction of cell matrix and of B-granules on $30-40 \%$ of B-cells surface within $15-30 \mathrm{~min}$. and on $85-95 \%$ of surface $2 \mathrm{~h}$ past injection of diabetogenic doses of DZBC and developing of 1 type of diabetes; $1.5-2 \mathrm{~h}$ later chemical complex disintegrates in B-cells; analogical results were obtained using tissue culture model of experience; b) elimination of $\mathrm{Zn}^{+2}$-ions from B-cells protect B-cells of destruction and of developing of experi-mental diabetes in 95-100\% animals; c)preventive not diabetogenic binding of $\mathrm{Zn}$ 
+2-ions in B-cells by not diabetogenic ligands as aminoacids (Figures 1a-1f) recovered Glutathion, Cystein and salts of Dithiocar-bamic acid, protect B-cells of destruction and of developing of diabetes in all animals for 12-24 h.

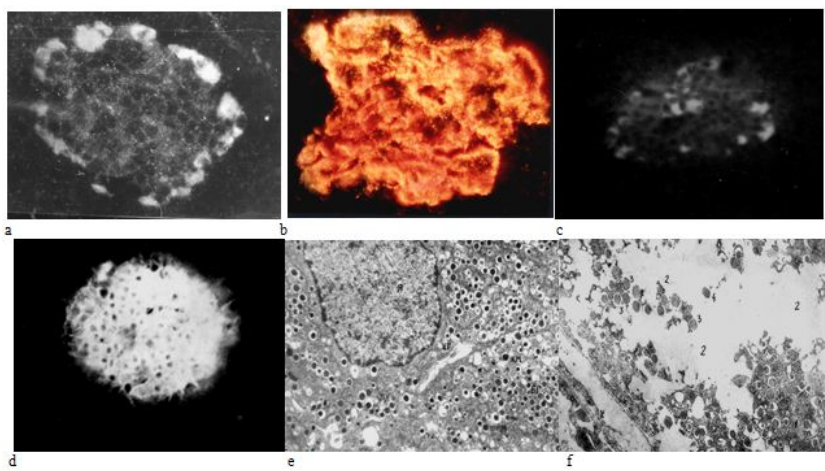

Figure 1: a) Frozen section of intact pancreas of Rabbit without staining. b) Past injection of Dithizon, $50,2 \mathrm{mg} / \mathrm{kg}$; red granules- complex "Dithizon-Zn" in B-cells. c) Frozen section of intact pancreas without staining; intensive fluorescence of complex "8-p(toluenesulphonylamino)quinoline-Zn" in B-cells. e) Transmission electron microscopy of B-cell of intact Rabbit. $f$ ) Transmission melectron microscopy of B-cell $2 \mathrm{~h}$ past injection of Dithizon: destruction of B-cell's matrix.

Oxidized Glutathion not containing $\mathrm{SH}$-group not protect Bcells interaction of $\mathrm{Zn}^{+2}$-ions with $\mathrm{DZBC}$ and as result of destruction as of developing of diabetes.

3. 1980-2018. Investigation of diabetogenic activity of the one of 16 derivatives of 8-oxyquinolin as Xanthurenic Acid (XA) unlike all other DZBC is synthesized in the organism of human as result of disturbances of Tryptophan [6] metabolism: a)mechanisms of diabetogenic action of $X A$; b) search of methods for suppression of synthesis of $X A$ in animals. Results: a) XA formed as other DZBC in B-cells of toxic complex with Zn +2 but accumulates in organism [7] slowly and diabetes developed on clinical aspect as 2 type; aggravation of diabetes caused by XA (Figure 2) is determined by destruction of capillaries wall, contacted B-cells contains chelate complexes with $\mathrm{Zn}^{+2}$ in islets that accompanied by $[8,9]$ disturbances of blood microcirculation; b) treatment of rats with diabetes induced by XA by Pyridoxine, $150 \mathrm{mg} / \mathrm{kg}$ per 2 days within 3-3.5 months result decreasing of xanthurenuria $0.366 \pm 0.14$ $\mathrm{mg} / 100 \mathrm{ml}$ until $0.118 \pm 0.008 \mathrm{mg} / 100 \mathrm{ml}$ (intact control: $0.035 \pm 0.005$ ) by decreasing of blood glucose level until $8.1 \pm$ $0.5 \mathrm{mM}$ from $12.6 \pm 0.6 \mathrm{mM}(\mathrm{p}<0.005)$ and by weakening symptoms of diabetes in animals.

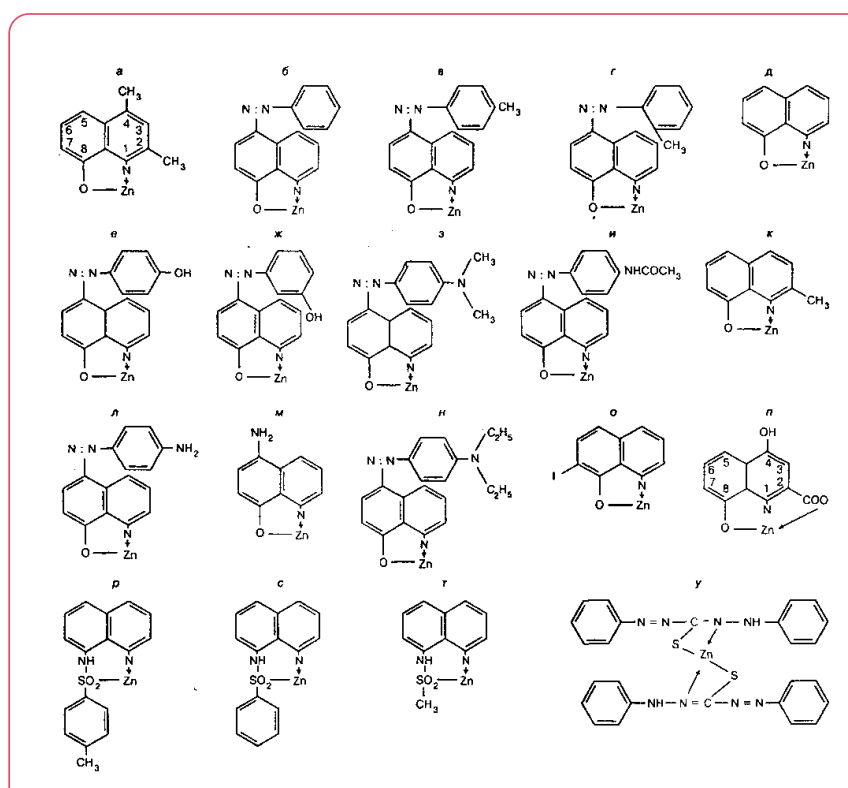

Figure 2: Complex salts of Diabetogenic Zincbinding Chelat Active Chemicals with $\mathrm{Zn}$-ions and its diabetogenic doses: a) 2,4-dimethyl-8-oxyquinolin, $35 \mathrm{mg} / \mathrm{kg}$. Б) 5-phenylaso-8oxyquinolin, $20 \mathrm{mg} / \mathrm{kg}$. B) 5-para (toluene)-8-oxyquinolin, 20 $\mathrm{mg} / \mathrm{kg}$. г) 5-orto- (toluene)-8-oxyquinolin, $40 \mathrm{mg} / \mathrm{kg}$. д) 8oxyquinolin, $50-60 \mathrm{mg} / \mathrm{kg}$. e) 5-para (diethylaminophenylaso)-8-oxyquinolin, $20 \mathrm{mg} / \mathrm{kg}$. ж) 5meta (hydroxyphenylaso)-8-oxyquinolin, $30 \mathrm{mg} / \mathrm{kg}$. 3) 5 para (dimethylaminophenylaso)-8-oxyquinolin, $45 \mathrm{mg} / \mathrm{kg}$. и) 5para(acetylami- nophenylaso)-8-oxyquinolin, $50 \mathrm{mg} / \mathrm{kg}$. $\mathrm{k}$ ) 8-oxyquinaldin, $10 \mathrm{mg} / \mathrm{kg}$. л) 5-para (aminophenylaso)-8oxyquinolin, $10 \mathrm{mg} / \mathrm{kg}$. M) 5-amino-8-oxyquinolin, 30 $\mathrm{mg} / \mathrm{kg}$. H) 5-para (diethylaminophenyla- so)-8-oxyquinolin, $40 \mathrm{mg} / \mathrm{kg}$. o) 9-oxy-7-jodoquinolin, 50-60 mg/kg. п) 4,8 dihydroxyquinolin-2 carboxylic acid (xantu- renic acid). p) 8para (toluenesulphonylamino)quinolin, $30-50 \mathrm{mg} / \mathrm{kg}$. c) $8-$ para (benzolsulphonylamino)quinolin, $30-100 \mathrm{mg} / \mathrm{kg}$. T) 8para (metansulphonylamino)quinolin, $40-81 \mathrm{mg} / \mathrm{kg}$. y) diphenylthiocarbazone (dithizon), 45-50 mg/kg.

\section{Financial Supporting}

1964-1976 by Lab of the Pathogenesis of diabetes of the Karaganda State Medical University; $1977-2016$ by family of G.G.Meyramov and G.A.Meyramov By Prof. Kohnert K.D , Institute of Diabetes "Gerhardt Katsch", Germany (1994-1997), by Prof. J.Turtle, a vice-president of the International Diabetes Federation (IDF), Sydney, Australia (1992) as by Prof. B.Tuch, University of New South Wales, Sydney, Australia (1992).

\section{References}

1. Lapin VI, Meiramov GG, Korchin VI, Satosin VA (1973) Mechanism of damage to the pancreatic islets in dithisone diabetes. Pathol Physiol \& Exper Therapy 4: 36-39.

2. Lasaris YA, Lasaris AY (1967) The role of zinc blockade in the pathogenesis of dithizone-induced diabetes. Probl Endokrinol (Mosk) 20: 90-94. 
3. Meurramov GG, Tusupbekova GT, Meiramova RG (1987) A histofluorimetric method of evaluating the insulin level of pancreatic islets. Probl Endokrinol (Mosk) 33: 49-51.

4. Meíramov GG, Andreeva AP, Konert KD (1997) Investigation of diabetogenic action of xanthurenic acid. Biull Eksp Biol Med 123: 669-672.

5. Meiramov GG, Trukhanov NI (1975) The ultrastructure of pancreatic beta cells in dithizone diabetes and its prevention by sodium diethyldithiocarbamate. Probl Endokrinol (Mosk) 21: 92-95.

6. Bekbergenov BM, Monastyrskaia AR, Glezer GA, Meiramov GG (1982) Determination of the leukocyte count in the urine using diagnostic strips. Lab Delo 2: 73-75.
7. Meĭramov GG, Kohnert KD, Turchin IS, Tusupbekova GT, Akhmetov AA, et al. (1990) The histochemical detection of insulin in a culture of pancreatic endocrine tissue by using the pseudoisocyanine and immunofluorescence methods. Probl Endokrinol (Mosk) 36: 66-69.

8. Meyramov G, Korchin V, Kocheryzkina N (1998) Diabetogenic activity of xanturenic acid determined by its chelating properties? Transplant Proc 30: 2682-2684.

9. Lapin VI, Korchin VI, Meiramov GG, Pal'mina TV, Satosin VF (1973) Effect of alloxan on the content of insulin and zinc in the pancreatic islets in experimental animals. Patol Fiziol Eksp Ter 17: $36-40$ 